\title{
Estimation of prevalence of white spot syndrome virus (WSSV) by polymerase chain reaction in Penaeus monodon postlarvae at time of stocking in shrimp farms of Karnataka, India: a population-based study
}

\author{
P. C. Thakur ${ }^{1}$, F. Corsin ${ }^{2}$, J. F. Turnbull ${ }^{3}$, K. M. Shankar ${ }^{1}$, N. V. Hao ${ }^{4}$, P. A. Padiyar ${ }^{1}$, \\ M. Madhusudhan ${ }^{1}$, K. L. Morgan ${ }^{2}$, C. V. Mohan ${ }^{1, *}$ \\ ${ }^{1}$ Fish Pathology \& Biotechnology Laboratory, Department of Aquaculture, University of Agricultural Sciences, College of \\ Fisheries, Mangalore 575002, India \\ ${ }^{2}$ Department of Veterinary Clinical Science \& Animal Husbandry, The University of Liverpool, Leahurst, Neston CH64 7TE, \\ United Kingdom \\ ${ }^{3}$ Institute of Aquaculture, University of Stirling, Stirling FK9 4LA, United Kingdom \\ ${ }^{4}$ Research Insitute for Aquaculture No. 2, 116 Nguyen Dinh Chieu Street, Ho Chi Minh City, Vietnam
}

\begin{abstract}
White spot disease (WSD) is at present the most serious viral disease affecting cultivated shrimp species globally. The causative agent, white spot syndrome virus (WSSV), is extremely virulent, has a wide host range and can also be transmitted from broodstock to their offspring. The shrimp postlarvae (PL) act as asymptomatic, latent carriers of the virus, and stocking of WSSV-infected PL has been reported as a risk factor for WSD outbreaks in culture ponds. However, there is no population-based study on WSSV prevalence in PL of shrimp. The present manuscript documents the approaches and the results in the estimation of prevalence of WSSV in PL populations of Penaeus monodon at the time of stocking. A maximum of 300 PL from each of the 73 batches of PL stocked at various farms in the west coast of India during September 1999 to January 2000 were tested for the presence of WSSV by 2-step nested PCR. Thirty-six (49\%) of the 73 batches tested positive for WSSV either by 1-step alone ( 3 batches) or after 2-step nested PCR (33 batches). Sub-samples of 5 PL each or 1 PL each tested to quantify the proportion of infected PL within batches showed that WSSV prevalence was very high in 1-step PCR-positive batches and low in 2-step PCR-positive batches. The study also showed that appropriate sampling and sample size were major factors in determining the prevalence of WSSV in PL populations, underlining the need for testing large samples of PL to reduce errors from falsely negative results.
\end{abstract}

KEY WORDS: WSSV $\cdot$ PCR $\cdot$ Penaeus monodon · Postlarvae $\cdot$ Prevalence $\cdot$ Aquatic epidemiology

\section{INTRODUCTION}

Ever since it was first reported following outbreaks in Japan and China (Nakano et al. 1994, Takahashi et al. 1994, Chou et al. 1995), white spot disease (WSD) has proved to be the most serious epidemic in cultured

${ }^{*}$ Corresponding author. E-mail: cv_mohan@yahoo.com shrimp throughout Asia (Wang et al. 1995, Wongteerasupaya et al. 1995, Lo et al. 1996a, Flegel 1997, Park et al. 1998, Sudha et al. 1998, Magbanua et al. 2000) and, more recently, in the Americas (Calderon et al. 2000). The causative agent, white spot syndrome virus (WSSV) is a bacilliform, double-stranded DNA virus (Wang et al. 1995, Lightner 1996). The taxonomic position of the virus is yet to be approved by the Interna- 
tional Committee on Taxonomy of Viruses (ICTV). The entire genome sequence of the virus has recently been reported. It is a $292.976 \mathrm{~kb}$ long, circular, doublestranded DNA representing an entirely new virus family, and a new family name 'Nimaviridae' has been proposed (van Hulten et al. 2001).

WSSV has a wide host range, affects almost all species of cultured shrimp (Lo et al. 1996b) and is extremely dangerous because of its ability to cause mass mortalities in culture ponds. Hence, it is regarded as a C-1 category pathogen (Lotz 1997). There is evidence of WSSV infection in the reproductive tissue of male and female Penaeus monodon broodstock (Lo et al. 1997, Mohan et al. 1997) and the postlarvae (PL) from infected $P$. monodon broodstock have been found to be infected with WSSV (Lo \& Kou 1998). Hence, P. monodon PL are considered as a major entry route for WSSV into culture ponds (Limsuwan 1997, Flegel \& AldaySanz 1998, Mushiake et al. 1999). Stocking of 1-step PCR-positive PL batches has also been associated with disease outbreaks and crop failure (Withyachumnarnkul 1999).

WSSV in India was first reported in 1994 along the east coast (Mohan et al. 1998) and quickly spread to the west coast and all the culture areas of the country (Shankar \& Mohan 1998), causing severe economic losses. Since then, it has become endemic to all the intensive as well as artisanal culture areas, with a pattern of cyclic epidemics.

The rapid and extensive spread of WSSV has been attributed to the movement of infected PL and frozen shrimps (Momoyama et al. 1994, Nakano et al. 1994, Nunan et al. 1998). Due to the pandemic nature of the disease, much emphasis has been given to prevention and early diagnosis of WSSV. For all these reasons, in recent years, screening of PL or broodstock for WSSV by PCR has been proposed to the shrimp-farming industry as a major component of disease-management strategies (Limsuwan 1997, Lo \& Kou 1998).

Several WSSV-diagnostic PCR methods have been developed for screening and early detection of the disease (Lightner 1996, Lo et al. 1996a, Takahashi et al. 1996, Kim et al. 1998, Maeda et al. 1998). A 2-step (nested) PCR (Lo et al. 1996b) has been developed into one of the most powerful tools for detecting the pathogen, and this has been used to screen carriers, shrimp larvae and spawners and to monitor WSSV in cultured shrimp (Lo et al. 1998).

The aim of the present investigation was to estimate the prevalence of WSSV in Penaeus monodon PL at the time of stocking on the west coast of India. The results presented in this paper are part of a larger epidemiological study on WSD. The present manuscript is the first document on WSSV prevalence in PL from a population-based study in which statistically based samples of PL batches were considered over a period of time. Besides its epidemiological relevance, the paper also identifies and discusses some practical issues regarding the methodology for effective screening of PL for WSSV by PCR.

\section{MATERIALS AND METHODS}

PL samples. Penaeus monodon PL samples were collected at the time of stocking from shrimp farms in Kundapur $\left(13^{\circ} 36^{\prime}\right.$ to $13^{\circ} 42^{\prime} N, 74^{\circ} 40^{\prime}$ to $74^{\circ} 44^{\prime}$ E), Karnataka, along the west coast of India. As part of the longitudinal observational study, a random sample of 100 shrimp ponds was selected, representing the shrimp farms around the Kundapur estuary. Of these, 70 ponds were enrolled in the investigation and data were collected on the PL batches stocked in each pond. A total of 73 stocking events took place in these ponds between September 1999 and January 2000. Farms were visited at each stocking event and a sample of 500 PL was collected by pooling scoop samples from all the delivery bags for each batch of PL prior to stocking. After qualitative and gross examination, the PL samples were then put in chilled water for 1 to $3 \mathrm{~h}$ and transferred to a field laboratory. Each PL batch was then divided into 8 sub-samples of $50 \mathrm{PL}$ each and a separate sub-sample of $100 \mathrm{PL}$. All the sub-samples were fixed in absolute methanol in separate cryovials and brought to the laboratory for PCR analysis. The overall protocol is illustrated in Fig. 3 (see 'Results' section).

Sample preparation and PCR analysis. Each subsample of 50 PL was considered as a separate sample for the PCR analysis and was processed separately using disposable equipment to avoid cross-contamination. Prior to DNA extraction, the anterior portion of all the PL was removed. DNA extraction was performed by an alkaline cell lysis method (Kiatpathomchai et al. 2001). Briefly, each sample of 50 PL was drained and thoroughly homogenised with $3 \mathrm{ml}$ of DNA extraction solution $(0.025 \%$ sodium dodecyle sulfate and $0.05 \mathrm{~N}$ $\mathrm{NaOH}$ ) in a sterile mortar. Approximately $500 \mu \mathrm{l}$ of the tissue homogenate was then transferred to a $1.5 \mathrm{ml}$ micro-centrifuge tube, boiled for $5 \mathrm{~min}$, and immediately placed at $4^{\circ} \mathrm{C}$ until use.

PCR was performed using the method described by Lo et al. (1996b) using primers 146F1/146R1 for the preliminary amplification and 146F2/146R2 for the second nested amplification. All the PCRs were carried out in $100 \mu \mathrm{l}$ of reaction mixture containing $3 \mu \mathrm{l}$ of template DNA (approximately $100 \mathrm{ng}$ ), $10 \mu \mathrm{l}$ of $10 \times$ reaction buffer $(750 \mathrm{mM}$ Tris/ $\mathrm{HCl} \mathrm{pH}: 9.0,200 \mathrm{mM}$ $\left(\mathrm{NH}_{4}\right)_{2} \mathrm{SO}_{4}, 0.1 \%$ Tween-20, $\left.15 \mathrm{mM} \mathrm{MgCl} 2\right), 100$ pmol of each primer, 2.5 units of Taq DNA polymerase 
(Hybaid-AGS Gold ${ }^{\mathrm{TM}}$, UK), $200 \mu \mathrm{M}$ of each dNTP and sterile double-distilled de-ionized water to make up the final volume. Amplification was performed in a thermocycler (PCR Express) using the following protocol: 1 cycle at $94^{\circ} \mathrm{C}$ for $4 \mathrm{~min}, 55^{\circ} \mathrm{C}$ for $1 \mathrm{~min}$ and $72^{\circ} \mathrm{C}$ for $2 \mathrm{~min}$; $39 \mathrm{cycles}$ at $94^{\circ} \mathrm{C}$ for $1 \mathrm{~min}, 55^{\circ} \mathrm{C}$ for $1 \mathrm{~min}$ and $72^{\circ} \mathrm{C}$ for $2 \mathrm{~min}$, followed by a final extension for $5 \mathrm{~min}$ at $72^{\circ} \mathrm{C}$. Electrophoresis was performed by loading $10 \mu \mathrm{l}$ of the amplified product onto $1.5 \%$ agarose gel with $1 \times$ TBE (Trizma, boric acid, EDTA) buffer. The gel was stained using ethidium bromide solution $(1 \mu \mathrm{g}$ $\mathrm{ml}^{-1}$ ) for $30 \mathrm{~min}$, and the bands were visualised by UV transillumination.

Samples that tested negative by 1-step PCR were subjected to the 2-step nested PCR using $10 \mu \mathrm{l}$ of the 1-step amplified product as a DNA template.

PCR controls. All PCRs were conducted according to PCR laboratory set-up specifications (Kwok \& Higuchi 1989, Dieffenbach et al. 1995) to avoid contamination. The steps in the PCR such as sample preparation, prePCR reagent preparation, post-PCR, and 2-step PCR were physically separated and performed in different rooms. DNA samples and PCR reagents were handled with positive displacement pipettes and tips with filter barriers to prevent carry-over of aerosols. Separate sets of equipment were used for sample preparation, pre-amplification, post-amplification and 2-step PCR work. Disposable gloves were worn at all times and were changed frequently at each step, and separate laboratory coats were worn for the pre-PCR and postPCR areas. Utmost care was taken to prevent sampleto-sample contamination. A negative control was always included in each PCR run; this contained all the PCR reagents except the template DNA and was processed and loaded immediately after the positive control at each step. This allowed a check on any carryover or cross-contamination.

PCR sensitivity assay. The limit of detection of the present PCR assay was tested by examining 10 -fold dilutions of DNA extracted from individual PL that were 1 -step and 2-step-positive by PCR. The positive extract was diluted in DNA extracted from uninfected individual PL that were negative by 2 -step PCR. These uninfected individual PL were obtained from a 2-step PCRnegative batch. The $10^{-6}$ dilution had an equivalent of approximately $100 \mathrm{fg}$ of total DNA extract from infected $\mathrm{PL}$, whereas the $10^{-9}$ dilution corresponded to approximately $100 \mathrm{ag}$. Three individual PL-positive by 1 -step PCR alone, and 4 individual PL-positive only by 2 -step PCR were each examined for the limit of detection.

Prevalence estimation. The prevalence of infection in batches was determined by testing a maximum of 300 individuals ( 6 sub-samples each of 50 PL) by PCR from each of the 73 batches of PL. This allowed the detection of WSSV with $95 \%$ confidence if it were pre- sent in at least $1 \%$ of the population in each batch of PL (Canon \& Roe 1982). Initially 200 PL (4 sub-samples each of $50 \mathrm{PL}$ ) from each batch were tested and the results recorded. The batches that were negative at this stage were then subjected to further testing until a positive result was obtained or 300 PL had been tested.

A batch was considered positive or infected when at least 1 sub-sample tested positive either by 1-step or 2-step PCR. A batch was considered 1-step positive when at least 1 sub-sample of that batch tested positive by 1-step PCR alone, and a batch was considered 2-step-positive if the sub-sample(s) tested positive only after 2-step nested PCR.

An additional 10 sub-samples, each containing 5 PL, were tested from each of the 1-step-positive batches. In order to assess the prevalence of infection in individual PL, 10 individual PL each from 1-step-positive batches, 2-step-positive batches and a 2-step-negative batch were also tested. These individual PL and subsamples of 5 PL were taken from sub-samples of the remaining $100 \mathrm{PL}$ from the respective batches.

\section{RESULTS}

\section{Limit of detection of PCR assay}

The results of the limit of detection assay (Table 1) showed that the 2-step nested PCR could detect WSSV DNA up to a dilution of 1:10 ${ }^{6}$ for a 1-step-positive sample whereas it could detect up to a dilution of $1: 10^{4}$ for a 2 -step-positive sample. The individual 2-step-positive PL used to carry out the limit of detection test were derived from 1-step-positive batches (Batches 1 and 3) since we could not find any individual PCR-positive PL

Table 1. Penaeus monodon. Limit of detection of the PCR assay for different levels of infected postlarvae (PL) from 1-step-positive batches. nd: not detectable

\begin{tabular}{|lcc|}
\hline Level of infection & 1-step PCR & 2-step PCR \\
\hline 1-step-positive PL & & \\
(heavily infected) & & \\
PL from Batch 1 & $1: 10^{4}$ & $1: 10^{6}$ \\
PL from Batch 2 & $1: 10^{1}$ & $1: 10^{5}$ \\
PL from Batch 3 & $1: 10^{2}$ & $1: 10^{6}$ \\
Average & $1: 10^{2.3}$ & $1: 10^{5.7}$ \\
& & \\
2-step-positive PL & & \\
(lightly infected) & & $1: 10^{4}$ \\
PL from Batch 1 & nd & $1: 10^{3}$ \\
PL from Batch 1 & nd & $1: 10^{2}$ \\
PL from Batch 3 & nd & $1: 10^{2}$ \\
PL from Batch 3 & nd & $1: 10^{2.75}$ \\
Average & nd & \\
\hline
\end{tabular}



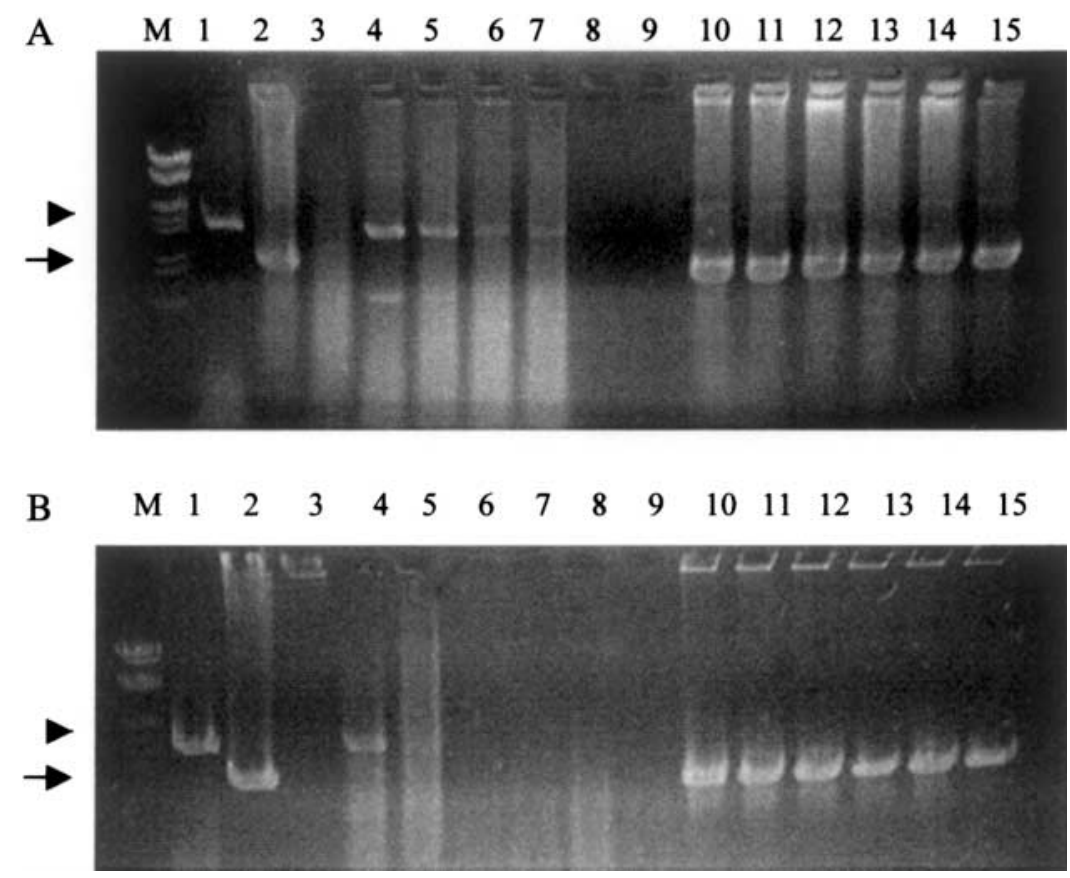

Fig. 1. Penaeus monodon. Limit of detection of 1-step and nested PCR for 2 different (A and B) 1-step-positive postlarvae (PL). M: DNA size marker ( $\lambda$ DNA double digest with EcoRI and HindIII); Lane 1: 1-step-positive control; Lane 2: 2-step-positive control; Lane 3: negative control; Lanes 4 to 9: 1-step PCR product of $10^{-1}$ to $10^{-6}$ dilution of DNA from infected PL; Lanes 10 to 15: nested PCR product of same. Note 1-step PCR product of $1447 \mathrm{bp}$ (arrowheads) and 2-step PCR product of $941 \mathrm{bp}$ (arrows)

Table 2. Penaeus monodon. Proportion of postlarvae (PL) batches testing positive for WSSV by PCR (with a sample size to detect a minimum of $1 \%$ prevalence). Total N: total number of PL batches tested

\begin{tabular}{|ccccc|}
\hline $\begin{array}{c}\text { Total } \\
\mathrm{N}\end{array}$ & $\begin{array}{c}\text { 1-step } \\
\text { PCR-positive } \\
\text { batches }\end{array}$ & $\begin{array}{c}\text { Batches tested } \\
\text { positive only by } \\
\text { 2-step PCR }\end{array}$ & $\begin{array}{c}\text { Total } \\
\text { positive } \\
\text { batches }\end{array}$ & $\begin{array}{c}\text { Total } \\
\text { batches tested } \\
\text { negative }\end{array}$ \\
\hline 73 & $3(4.11 \%)$ & $33(45.21 \%)$ & $36(49.32 \%)$ & $37(50.68 \%)$ \\
\hline
\end{tabular}

(out of $30 \mathrm{PL}$ tested) from the group of 2-step-positive PL batches. Fig. 1 shows the limit of detection result of both 1-step and 2-step PCR for 2 different 1-step-positive PL and Fig. 2 shows the limit of detection result of the 2step PCR for 2 different 2-step-positive PL. Here, a 1-step-positive sample refers to individual PL tested positive by 1-step PCR alone and a 2-steppositive sample refers to individual PL testing positive only after 2-step PCR.

\section{Prevalence of WSSV in PL population}

Out of 73 batches of PL tested, a total of 36 were positive for WSSV either by 1-step or 2-step nested PCR (Table 2). This suggested that approximately $49 \%$ (36 of $73 ; 95 \%$ confidence interval, $\mathrm{CI}=37.4$ to $61.3 \%$ ) of the $\mathrm{PL}$ batches stocked around Kundapur estuary carried WSSV. Amongst the tested batches, only 3 ( 3 of $73=4 \%$ ) were positive by 1-step PCR. The remaining 37 batches were negative ( 37 of $73=51 \%$ ) by nested PCR. The details of the PCR results of 50 PL subsamples from the positive batches are given in Table 3 and the approaches with which sub-samples were obtained from various batches for PCR analysis is displayed on the flow chart in Fig. 3.

Examination of the distribution of 2step-positive results of the sub-samples of $50 \mathrm{PL}$ taken from each of the

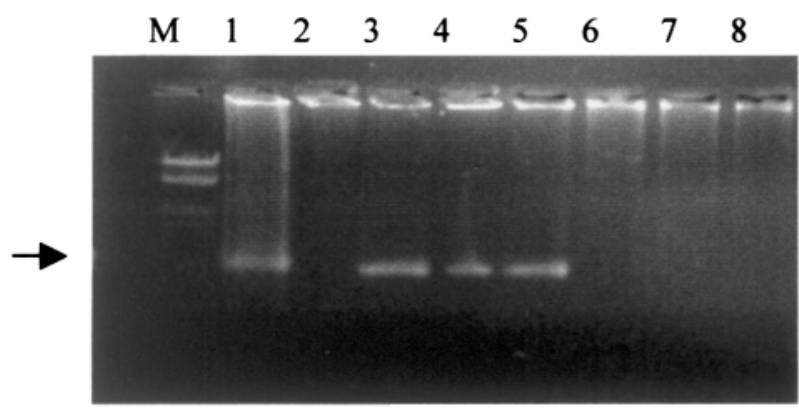

$\mathbf{A}$

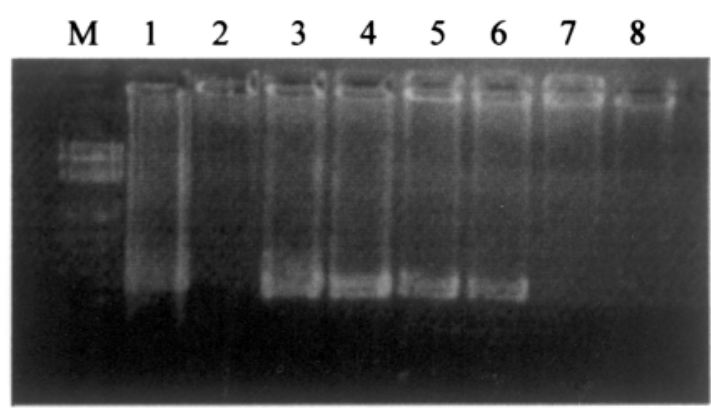

B

Fig. 2. Penaeus monodon. Limit of detection of the nested PCR for 2 different (A and B) 2-step-positive postlarvae (PL). M: DNA size marker ( $\lambda$ DNA double digest with EcoRI and HindIII); Lane 1: 2-step-positive control; Lane 2: negative control; Lanes 3 to 8: nested PCR product of $10^{-1}$ to $10^{-6}$ dilution of DNA from infected PL. Note 2-step PCR product of $941 \mathrm{bp}$ (arrow) 
2-step-positive batches showed that in the majority of batches (25 of $73=34 \%$ ) only 1 sub-sample $(1 / 4,1 / 5$, 1/6) was positive out of 4,5 or 6 tested. In $7 \%$ (5 of 73 ) batches, 2 sub-samples tested positive (2/4) and in $4 \%$ (3 of 73), 3 sub-samples were positive (3/4). None of the batches was positive in as many as 4 sub-samples.

In the 1-step-positive batches, all 4 sub-samples of 50 PL from each batch were positive. In the first 2 batches (Batches 1 and 2), all the sub-samples were 1-step-positive, whereas in the third batch (Batch 3), 2 sub-samples were 1-step-positive and the other 2 were 2 -steppositive. When the additional sub-samples of $5 \mathrm{PL}$ were tested from the 1-step-positive batches, they were all found to be positive by 1 -step or 2-step PCR. There was, however, a significant difference (Fisher's exact test, $\mathrm{p}<0.05$ ) in the numbers positive by 1 - and 2-step PCR amongst different batches (Table 4).

\section{Prevalence of WSSV in individual PL from 1-step and 2-step WSSV-positive batches}

Ten individual PL randomly selected from all three 1-step-positive batches, three 2-step-positive batches and one 2-step negative batch were analysed, and the results are shown in Table 5.

In all the 1-step PCR-positive batches 10 of 10 $(100 \%)$ of the PL were positive, and they differed significantly amongst batches (Fisher's exact test, $\mathrm{p}<0.05)$ in the proportion of 1-step-positive PL. In the case of 2-step-positive batches $(3 / 4,2 / 4,1 / 4)$ and the 2-step negative batch (0/6), not a single PL was found to be positive, suggesting a low prevalence.

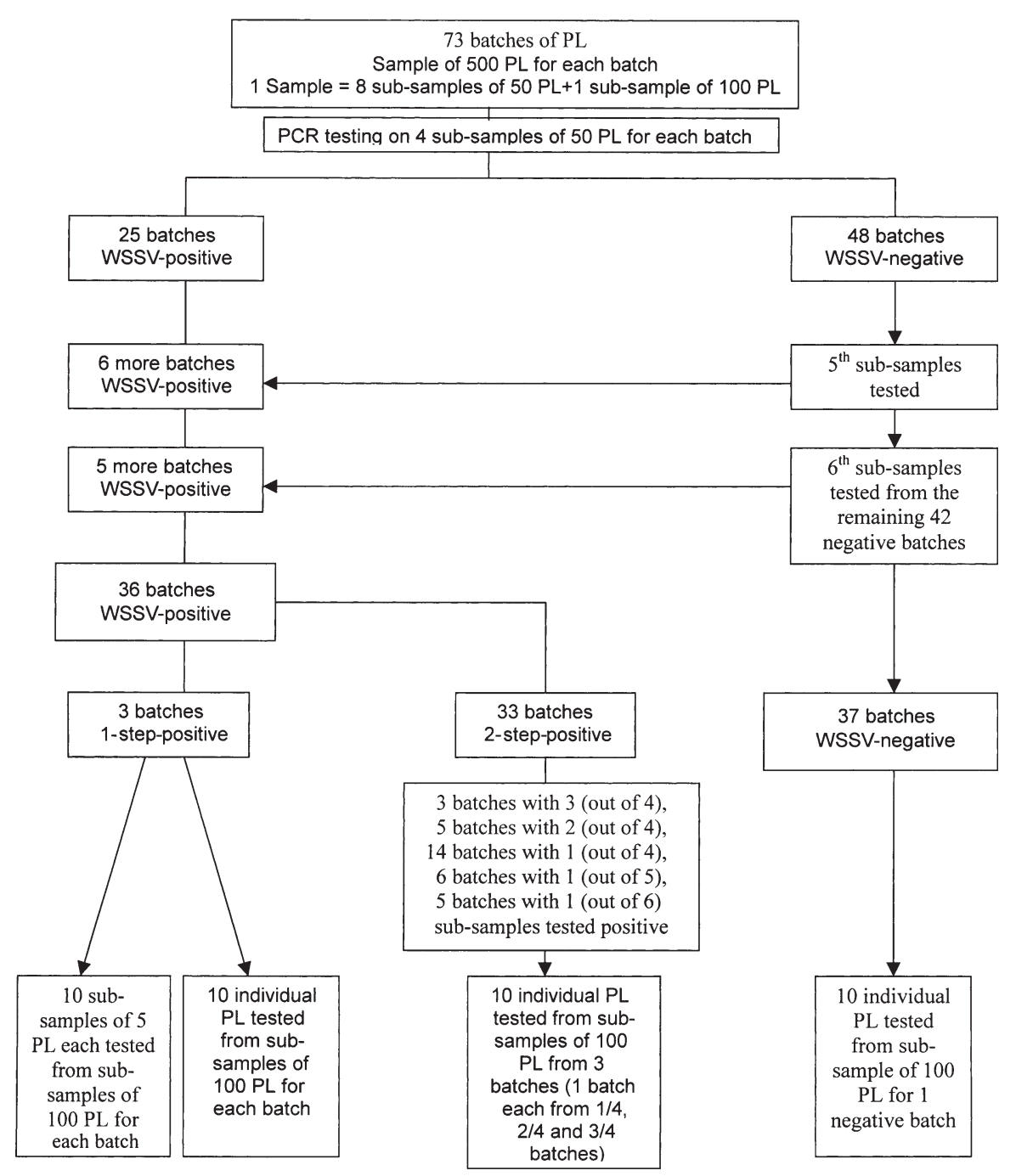

Fig. 3. Penaeus monodon. Flow diagram showing sampling scheme and results for subsample processing of PCR tests

\section{DISCUSSION}

The present study investigated the prevalence of WSSV in Penaeus monodon PL at the time of stocking in Indian shrimp farms. The point prevalence of WSSVinfected PL batches in the entire population of PL batches stocked in the Kundapur estuary between September 1999 and January 2000 was $49 \%$, with a $95 \%$ CI of 37.4 to $61.3 \%$. A sample size of $300 \mathrm{PL}$ from each batch was used, since detecting a prevalence of $\geq 1 \%$ or above in a population of $\geq 10000$ individuals requires a sample of 297 PL (Canon \& Roe 1982). Thus, the prevalence of $49 \%$ refers to the probability of a sample of PL batches testing positive by 2-step PCR at a sampling level selected to detect prevalence of WSSV infection of $1 \%$ or more in the population of PL within a batch.

The limit of detection of the PCR assay was shown to be much lower than the equivalent of $1 \mathrm{PL}$ in 50 . In fact, at $1: 10^{5}$ to $1: 10^{6}$ dilutions, WSSV DNA could be detected by the nested PCR. At this dilution the original template DNA from the infected tissue corresponded to $1 \mathrm{pg}$ to $10 \mathrm{fg}$. Lo et al. (1996b) also detected WSSV DNA at up to $10^{-9}$ dilution (1 fg of template DNA) from deproteinized DNA extract from muscle tissue of an infected adult Penaeus monodon shrimp. 
Table 3. Penaeus monodon. PCR results of sub-samples of 50 postlarvae (PL) from WSSV-positive batches. ++: 1-steppositive, +: 2-step-positive, NA: not analysed

\begin{tabular}{|c|c|c|c|c|c|c|c|}
\hline \multirow{2}{*}{$\begin{array}{l}\text { PL } \\
\text { batch } \\
\text { no. }\end{array}$} & \multicolumn{6}{|c|}{ PCR results for sub-samples } & \multirow{2}{*}{$\begin{array}{l}\text { Proportion of } \\
\text { WSSV-positive } \\
\text { sub-sample }\end{array}$} \\
\hline & 1 st & 2nd & $3 r d$ & 4 th & 5 th & 6 th & \\
\hline 1 & ++ & ++ & ++ & ++ & NA & NA & 4 of 4 \\
\hline 2 & ++ & ++ & ++ & ++ & NA & NA & 4 of 4 \\
\hline 3 & + & + & ++ & ++ & NA & NA & 4 of 4 \\
\hline 4 & + & + & + & - & NA & NA & 3 of 4 \\
\hline 5 & - & + & + & + & NA & NA & 3 of 4 \\
\hline 6 & - & + & + & + & NA & NA & 3 of 4 \\
\hline 7 & + & + & - & - & NA & NA & 2 of 4 \\
\hline 8 & - & + & - & + & NA & NA & 2 of 4 \\
\hline 9 & + & - & + & - & NA & NA & 2 of 4 \\
\hline 10 & + & + & - & - & NA & NA & 2 of 4 \\
\hline 11 & - & - & + & + & NA & NA & 2 of 4 \\
\hline 12 & - & + & - & - & NA & NA & 1 of 4 \\
\hline 13 & - & - & + & - & NA & NA & 1 of 4 \\
\hline 14 & - & + & - & - & NA & NA & 1 of 4 \\
\hline 15 & - & - & - & + & NA & NA & 1 of 4 \\
\hline 16 & - & + & - & - & NA & NA & 1 of 4 \\
\hline 17 & + & - & - & - & NA & NA & 1 of 4 \\
\hline 18 & - & - & + & - & NA & NA & 1 of 4 \\
\hline 19 & - & - & + & - & NA & NA & 1 of 4 \\
\hline 20 & - & - & + & - & NA & NA & 1 of 4 \\
\hline 21 & - & + & - & - & NA & NA & 1 of 4 \\
\hline 22 & - & - & - & + & NA & NA & 1 of 4 \\
\hline 23 & - & + & - & - & NA & NA & 1 of 4 \\
\hline 24 & - & - & - & + & NA & NA & 1 of 4 \\
\hline 25 & + & - & - & - & NA & NA & 1 of 4 \\
\hline 26 & - & - & - & - & + & NA & 1 of 5 \\
\hline 27 & - & - & - & - & + & NA & 1 of 5 \\
\hline 28 & - & - & - & - & + & NA & 1 of 5 \\
\hline 29 & - & - & - & - & + & NA & 1 of 5 \\
\hline 30 & - & - & - & - & + & NA & 1 of 5 \\
\hline 31 & - & - & - & - & + & NA & 1 of 5 \\
\hline 32 & - & - & - & - & - & + & 1 of 6 \\
\hline 33 & - & - & - & - & - & + & 1 of 6 \\
\hline 34 & - & - & - & - & - & + & 1 of 6 \\
\hline 35 & - & - & - & - & - & + & 1 of 6 \\
\hline 36 & - & - & - & - & - & + & 1 of 6 \\
\hline
\end{tabular}

Table 5. Penaeus monodon. PCR results of the individual postlarvae (PL) tested from sub-samples of 100 PL from different batches. N: number of PL tested

\begin{tabular}{|lcccc|}
\hline PL batches & N & $\begin{array}{c}\text { No. of } \\
\text { 1-step- } \\
\text { positive PL }\end{array}$ & $\begin{array}{c}\text { No. of PL } \\
\text { positive only } \\
\text { by 2-step PCR }\end{array}$ & $\begin{array}{c}\text { No. of } \\
\text { negative } \\
\text { PL }\end{array}$ \\
\hline 2-step-negative batch & 10 & 0 & 0 & 10 \\
2-step-positive batch & & & & \\
3/4 & 10 & 0 & 0 & 10 \\
2/4 & 10 & 0 & 0 & 10 \\
1/4 & 10 & 0 & 0 & 10 \\
1-step-positive batch & & & & 0 \\
Batch 1 & 10 & 3 & 0 & 0 \\
Batch 2 & 10 & 10 & 9 & 0 \\
Batch 3 & 10 & 1 & & \\
\hline
\end{tabular}

Table 4. Penaeus monodon. PCR results of the sub-samples (5 postlarvae, PL, each) tested from sub-samples of $100 \mathrm{PL}$ from the 1-step-positive batches. Total N: total number of sub-samples tested

\begin{tabular}{|lccc|}
\hline $\begin{array}{l}\text { 1-step- } \\
\text { positive } \\
\text { batches }\end{array}$ & Total N & $\begin{array}{c}\text { No. of 1-step- } \\
\text { positive sub- } \\
\text { samples }\end{array}$ & $\begin{array}{c}\text { No. of sub-samples } \\
\text { positive only by } \\
\text { 2-step PCR }\end{array}$ \\
\hline Batch 1 & 10 & 1 & 9 \\
Batch 2 & 10 & 10 & 0 \\
Batch 3 & 10 & 2 & 8 \\
\hline
\end{tabular}

The limit of detection may vary, depending on the initial quantity of target DNA in the original sample or the template DNA. However, quantification was not performed in either study to estimate the concentration of WSSV DNA in the samples tested. The assay demonstrated that 2-step nested PCR was $10^{3}$ to $10^{4}$ times more sensitive in detecting WSSV DNA than the 1-step PCR alone. This supports the results of nested PCR sensitivity for WSSV detection as reported by Lo et al. (1996b). This would suggest that samples which are 1-step PCR-positive must have at least $10^{3}$ to $10^{4}$ times more viral DNA than samples revealed as positive only by 2-step nested PCR. Based on this, we scored the PL batches and the individual PL as heavily infected (1-step-positive) and lightly infected (2-step-positive).

In our limit of detection assay, we used DNA extracted from uninfected shrimp (2-step negative) as the diluting medium instead of the dilution buffers or double-distilled deionised water, since PCR sensitivity may tend to be lower in the presence of excess shrimp genomic DNA. This provided a more realistic estimate of the sensitivity of the nested PCR procedure in a routine screening situation where only 1 shrimp may be infected out of several in a sample. The present nested PCR technique was able to detect a minimum equivalent to 1 heavily infected PL (1-step-positive) in 1 million. Similarly, for the lightly infected PL (2-step-positive), the minimum and maximum limits of detection were the equivalent of 1 in 10000 and 100 respectively. Although the sensitivity of the nested PCR was sufficient to detect the presence of infected PL in large sample sizes, it was often more convenient to conduct PCR analysis on sub-samples of 30 to $50 \mathrm{PL}$ for easier handling and processing.

Variations in the limit of detection from different individuals could be attributable to the level of viral load in the initial sample. Thus, by a dilution technique with PCR, an indirect quantal assay can be performed to asses the infection level/viral load in individuals or groups. However, 
the possibility of false negatives cannot be ruled out where the viral load or the prevalence is extremely low. A PCR-negative status means that the WSSV target DNA is below the detectable limit in the template DNA added to the reaction mixture, and does not guarantee WSSV-free status. Further, different PCR assays would offer different levels of sensitivity, depending on the preservation method, DNA extraction method, template concentration and the size of amplicons (Sambrook et al. 1989, Cha \& Thilly 1995). For instance, a sample that tests positive at first amplification by 1 diagnostic PCR protocol may test positive only after re-amplification by a less sensitive protocol. Similarly, a 2-step-positive sample tested by a highly sensitive protocol may test (falsely) negative by a less sensitive protocol. DNA extraction methods such as phenol-chloroform extraction or hot phenol extraction can be superior in terms of recovery of DNA and the stability of DNA, but they are time-consuming and expensive and this negates the benefit of rapid PCR or may not be feasible for large numbers of samples. Such extensive DNA extraction procedures must also be weighed against the increasing risk of sample contamination and loss of DNA at each manipulation step. In a more recent study, the PCR sensitivity was reported to be sufficient when using the template DNA prepared from WSSV-infected samples by the alkaline extraction method (Kiatpathomchai et al. 2001). In the present investigation, the combination of alkaline DNA extraction and 2-step nested PCR (Lo et al. 1996b) proved to be rapid and sensitive.

The most widely used fixative for PCR analysis is ethanol, but for our purpose we substituted methanol because of the non-availability of ethanol in the large quantity required for this study. The samples were stored in absolute methanol for a period of 3 to 6 mo prior to PCR analysis. The duration for which the samples are maintained in the fixative is also reported to be critical, as the type of fixative and certain fixatives also affect the ability of PCR to effectively amplify a larger target sequence (Greer et al. 1995). The possible impact of methanol towards lowering the recovery of intact DNA and the efficiency of subsequent PCR amplification is not known. However, from our limit of detection result, it is evident that there may be little or no impact on WSSV detection by the present method arising from such effects.

A significant aspect of the results was the variability in proportion of sub-samples that were positive in different 2-step-positive batches, especially when there was low levels of infection. The majority of the 2-steppositive batches had only 1 positive sub-sample out of 4,5 or 6 tested and in no case were all the sub-samples positive. This clearly shows that when a batch is only 2 -step-positive, the prevalence of infected individuals in the batch might be very low. This is clear from the fact that the other 150, 200 or 250 shrimp in such PL batches gave negative test results (since the limit of detection was $<1 / 50$ ). Testing 150 individuals allows $95 \%$ confidence in detecting up to a minimum of $2 \%$ prevalence. Therefore, it appears that these batches had a prevalence below $2 \%$. These results suggest that batches with low WSSV prevalence might yield some samples that test positive and others that test negative even when tested by the same PCR protocol; this could occur when very few, unevenly distributed, infected PL are present in a population. In commercial screening practices, usually 25 to $50 \mathrm{PL}$ are tested for assessing the infection status of PL batches, which may usually number up to 100000 or more PL, representing the progeny of several spawners. This may result in a high probability of sampling error and consequent falsely negative results. An earlier report (Withyachumnarnkul 1999) also documented that such false negatives are likely, and it was suggested that 150 individuals be homogenised instead of 50. Essentially, the results of our study confirm that variation in the results of 2-step PCR using individual samples of $50 \mathrm{PL}$ as commonly used in commercial testing carries a significant risk of obtaining a falsely negative result for the population being tested. Testing 50 or 150 individuals from a population of infinite size allows $95 \%$ confidence of detecting 5 and $2 \%$ prevalence respectively. Assaying a minimum of 300 PL from a population either pooled or in sub-samples of 50 PL would further reduce the probability of falsely negative results. Such a procedure is essential in epidemiological studies concerning risk-factor analysis, in which a very low prevalence of infection in a batch has to be detected.

In this study we found that all sub-samples of 5 PL and individual PL tested from the 100 PL groups of the three 1-step-positive batches were positive either by 1-step or 2-step nested PCR. In contrast, all the subsamples of individual PL taken from the 2-step-positive batches tested negative. These results further substantiate the higher prevalence of WSSV in 1-step-positive batches and lower prevalence in 2-step-positive batches. Similarly it was found that in some of the 1step-positive batches, the proportion of 1-step-positive PL (heavily infected) might be very high (as in the case of Batch 2), whereas in others there might be a very low number of heavily infected PL.

A critical aspect of this study was the diagnostic test used to determine infection status. PCR detects only a fragment of DNA. Whether the virus is viable or infectious cannot be known, and a non-viable virus present on the sample surface can also contribute to a PCRpositive result. Due to lack of a continuous shrimp cell line, PCR has been the sole and routine diagnostic tool in detecting WSSV infection in latent carriers or lightly 
infected shrimp. On the other hand, because of the exquisite sensitivity of 2-step nested PCR, passive contamination is a major concern. The sub-samples of $5 \mathrm{PL}$ each and the individual PL were taken from the PL 100 sub-samples fixed in 1 cryovial for the respective batches. The possibility of surface contamination from one PL to the other cannot be ruled out. However, these PL were fixed intact and live and there was no damage to the tissue or release of potentially infectious tissue fluids or haemolymph that could cause contamination. Hence, the possibility of such passive contamination is unlikely. Moreover, all these sub-samples and individual PL were processed using separate equipment to further reduce any cross-contamination.

The present study examined the PL at the time of stocking and not from hatcheries. This provided a better assessment of the level of infection introduced to the pond with the PL. Transport stress could have caused prepatent infections to become transitional or patent. Earlier reports have suggested that development from prepatent to transition or patent stage of infection occurred due to stress caused by pereiopod excision (Peng et al. 1998) and spawning stress (Lo et al. 1997), bringing the virus level in the sample to a detectable limit of 1-step PCR from 2-step PCR, thus improving the chance of detection. Transport stress has also been reported to affect the health quality of PL (Chanratchakool et al. 1998). However, no data on the infection status of the PL batches from the hatcheries was collected, and therefore it is not possible to comment on the effect of transportation. During the sample handling, the PL were placed in chilled water for 1 to $3 \mathrm{~h}$ prior to fixation, which would also stress them. The possibility of enhancement of infection status and thereby an apparent increase in WSSV prevalence within batches during sample handling cannot be ruled out.

This investigation looked into the prevalence status of WSSV in various discrete PL populations at the time of stocking in a major artisanal shrimp farming area on the west coast of India. Previously, there have been very few studies on WSSV prevalence in PL. In an earlier study, while monitoring WSSV in Ecuador (Calderon et al. 2000), the prevalence in hatchery tanks varied from 15 to $92 \%$ in different provinces, with sample sizes of $150 \mathrm{PL}$ per batch. In another study carried out in India along the west coast (Otta et al. 1999), $5 \%$ of the PL batches tested were positive by 1-step PCR, whereas $48 \%$ were positive by nested PCR with a sample size of 20 to 30 PL per hatchery. In this study we found that $49 \%$ of the PL batches stocked in the enrolled ponds were positive for WSSV, of which only $4 \%$ were positive by 1 -step PCR. This, however, is an estimation of point prevalence and there could be temporal and spatial variations. These results substan- tiate the persistence of WSSV in Peneaus monodon PL populations in India. In recent years the prevalence and the viral load entry along with PL batches have been suggested to play a role in WSS outbreaks (Lo et al. 1998). The estimation of prevalence of infection within batches is difficult, and this study represents an attempt to do so. Evaluation of a reliable protocol to quantify the viral load and prevalence of infection within batches would be useful in epidemiological studies.

Acknowledgements. We are grateful to Richard Callinan, Pornlerd Chanratchakool, Michael Phillips, Ian MacRae and Rohana Subasinghe, who helped during the preliminary palnning of the study. We would like to thank Iqlas Ahmed and K. S. Ramesh for their help in implementing the project. We would like to thank also the Brackish Water Fish Farming Development Agency for supplying the list of farmers. We would like to thank all the farmers and hatchery owners for extending their co-operation and support during the study. This study was a part of a larger epidemiological study on WSD. The project was supported by the Department for lnternational Development (DFID), UK, through Project No. R7051 of the Strategy for Research on Renewable and Natural Resources Programme.

\section{LITERATURE CITED}

Calderon J, Bayot B, Betaycourt I, Aldayde Graindorge V (2000) Monitoring study of white spot syndrome virus in Ecuador. Abstract book, World Aquaculture Society, Nice (Spec Publ No. 28)

Canon RM, Roe RT (1982) Livestock disease surveys: a field manual for veterinarians. Australian Government Publishing Service, Canberra

Cha RS, Thilly WG (1995) Specificity, efficiency and fidelity of PCR. In: Dieffenbach CW, Dveksler GS (eds) PCR primer: a laboratory manual. Cold Spring Harbor Laboratory Press, Cold Spring Harbor, NY, p 37-52

Chanratchakool P, Turnbull JF, Funge-Smith SJ, MacRae IH, Limsuwan C (1998) Health management in shrimp ponds, 3rd edn. Aquatic Animal Health Research Institute, Bangkok

Chou HY, Huang CY, Wang CH, Chiang HC, Lo CF (1995) Pathogenicity of baculovirus infection causing white-spot syndrome in cultured penaeid shrimp in Taiwan. Dis Aquat Org 23:165-173

Dieffenbach CW, Dragon EA, Dveksler GS (1995) Setting up a PCR laboratory. In: Dieffenbach CW, Dveksler GS (eds) PCR primer: a laboratory manual. Cold Spring Harbor Laboratory Press, Cold Spring Harbor, NY, p 7-16

Flegel TW (1997) Special topic review: major diseases of the black tiger prawn (Penaeus monodon) in Thailand. World J Microbiol Biotechnol 13:433-442

Flegel TW, AldaySanz V (1998) The crisis in Asian shrimp aquaculture: current status and future needs. J Appl Ichthyol 14:269-273

Greer CE, Wheeler CM, Manos MM (1995) PCR amplification from paraffin-embedded tissues: sample preparation and the effects of fixation. In: Dieffenbach CW, Dveksler GS (eds) (1995) PCR primer: a laboratory manual. Cold Spring Harbor Laboratory Press, Cold Spring Harbor, NY, p 99-112 
Kiatpathomchai W, Boonsaeng V, Tassanakajon A, Wongteerasupaya C, Jitrapakdee S, Panyim S (2001) A nonstop, single tube, semi-nested PCR technique for grading the severity of white spot syndrome virus infections in Penaeus monodon. Dis Aquat Org 47:235-239

Kim CK, Kim PK, Sohn SG, Sim DS and 6 others (1998) Development of polymerase chain reaction procedure for detection of baculovirus associated with white spot syndrome (WSBV) in penaeid shrimp. J Fish Dis 21:11-17

Kwok S, Higuchi R (1989) Avoiding false positives with PCR. Nature 339:237-238

Lightner DV (1996) A handbook of pathology and diagnostic procedures for diseases of penaeid shrimp. World Aquaculture Society, Baton Rouge, LA

Limsuwan C (1997) Reducing the effects of white-spot baculovirus using PCR screening and stressors. Newsl Aquat Anim Health Res Inst 6:1-2

Lo CF, Kou GH (1998) Virus-associated white spot syndrome of shrimp in Taiwan: a review. Fish Pathol 33:365-371

Lo CF, Leu JH, Ho CH, Chen CH and 8 others (1996a) Detection of baculovirus associated with White spot syndrome (WSBV) in penaeid shrimps using polymerase chain reaction. Dis Aquat Org 25:133-141

Lo CF, Ho CH, Peng SE, Chen $\mathrm{CH}$ and 7 others (1996b) White spot syndrome baculovirus (WSBV) detected in cultured and captured shrimp, crabs and other arthropods. Dis Aquat Org 27:215-225

Lo CF, Ho CH, Chen CH, Liu KF and 9 others (1997) Detection and tissue tropism of white spot syndrome baculovirus (WSBV) in captured brooders of Penaeus monodon with a special emphasis on reproductive organs. Dis Aquat Org 30:53-72

Lo CF, Chang YS, Cheng CT, Kou GH (1998) PCR monitoring of cultured shrimp for white spot syndrome virus (WSSV) infection in growout ponds. In: Flegel TW (ed) Advances in shrimp biotechnology. National Center for Genetic Engineering and Biotechnology, Bangkok, p 281-286

Lotz JM (1997) Special topic review: viruses, biosecurity and specific-pathogen-free stocks in shrimp aquaculture. World J Microbiol Biotechnol 13:405-413

Maeda M, Kasornchandra J, Itami T, Suzuki N and 6 others (1998) Detection of penaeid rod-shaped DNA virus (PRDV) in wild caught shrimp and other crustaceans. Fish Pathol 33:373-380

Magbanua FO, Karlo TW, Veronica PM, Catalino GA and 6 others (2000) White spot syndrome virus in the Philippines. Dis Aquat Org 42:77-82

Mohan CV, Sudha PM, Shankar KM, Hegde A (1997) Vertical transmission of white spot baculovirus in shrimps - a possibility? Curr Sci (Bangalore) 73:109-110

Mohan CV, Shankar KM, Kulkarni S, Sudha PM (1998) Histopathology of cultured shrimp showing gross signs of yellow head syndrome and white spot syndrome during 1994 Indian epizootics. Dis Aquat Org 34:9-12

Momoyama K, Hiraoka M, Nakano H, Koube H, Inouye K, Oseko N (1994) Mass mortality of cultured kuruma shrimp Penaeus japonicus in Japan in 1993: histopathological study. Fish Pathol 29:141-148

Mushiake K, Shimizu K, Satoh J, Mori K, Arimoto M, Ohsumi S, Imaizumi K (1999) Control of penaeid acute viremia

Editorial responsibility: Timothy Flegel,

Bangkok, Thailand
(PAV) in Penaeus japonicus: selection of eggs based on the PCR detection of the causative virus (PRDV) from receptaculum seminis of spawned broodstock. Fish Pathol 34: 203-207

Nakano H, Koube H, Umezawa S, Momoyama K, Hiraoka M, Inouye $\mathrm{K}$, Oseko $\mathrm{N}$ (1994) Mass mortalities of cultured kuruma shrimp, Penaeus japonicus in Japan in $1993-$ epizootiological survey and infection trials. Fish Pathol 29: 135-139

Nunan LM, Poulos BF, Lightner DV (1998) The detection of white spot syndrome virus (WSSV) and yellow head virus (YHV) in imported commodity shrimp. Aquaculture 160: $19-30$

Otta SK, Shubha G, Joseph B, Chakraborty A, Karunasagar I, Karunasagar I (1999) Polymerase chain reaction (PCR) detection of white spot syndrome virus (WSSV) in cultured and wild crustaceans in India. Dis Aquat Org 38: $67-70$

Park JH, Lee YS, Lee S, Lee Y (1998) An infectious viral disease of penaeid shrimp newly found in Korea. Dis Aquat Org 34:71-5

Peng SE, Lo CF, Liu KF, Kou GH (1998) The transition from pre-patent to patent infection of white spot syndrome virus (WSSV) in Penaeus monodon triggered by pereiopod excision. Fish Pathol 33:395-400

Sambrook J, Fritch EF, Maniatis T (1989) Molecular cloning: a laboratory manual, 2nd edn. Cold Spring Harbor Laboratory, Cold Spring Harbor, NY

Shankar KM, Mohan CV (1998) Epidemiological aspects of viral diseases of shrimps in India-a review. J Aquacult Trop 13:43-49

Sudha PM, Mohan CV, Shankar KM, Hegde A (1998) Relationship between white spot syndrome virus infection and clinical manifestation in Indian cultured penaeid shrimp. Aquaculture 167:95-101

Takahashi Y, Itami T, Kondo M, Maeda M, Fuji R, Tomonga S, Supamattaya K, Boonyaratpalin S (1994) Electron microscopic evidence of bacilliform virus infection in Kuruma shrimp (Penaes japonicus). Fish Pathol 29:121-125

Takahashi Y, Itami T, Maeda M, Suzuki N and 9 others (1996) Polymerase chain reaction amplification of bacilliform virus (RV-PJ) DNA in Penaeus japonicus and systemic ectodermal and mesodermal baculovirus (SEMBV) DNA in Penaeus monodon. J Fish Dis 19:388-403

van Hulten MCW, Witteveldt J, Peters S, Kloosterboer N and 5 others (2001) The white spot syndrome virus DNA genome sequence. Virology 286:7-22

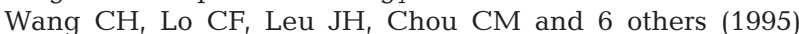
Purification and genomic analysis of baculovirus associated with white spot syndrome (WSS) of Penaeus monodon. Dis Aquat Org 23:239-242

Withyachumnarnkul B (1999) Results from black tiger shrimp Penaeus monodon culture ponds stocked with postlarvae PCR-positive or -negative for white-spot syndrome virus (WSSV). Dis Aquat Org 39:21-27

Wongteerasupaya C, Vickers JE, Sriurairatana S, Nash GL and 6 others (1995) A non-occluded, systemic baculovirus that occurs in cells of ectodermal and mesodermal origin and causes high mortality in the black tiger prawn Penaeus monodon. Dis Aquat Org 21:69-77

Submitted: August 9, 2001; Accepted: January 11, 2002 Proofs received from author(s): May 21, 2002 